\title{
RETÓRICA DE LA MIRADA SOBRE LA BASE DE LA INTERCULTURALIDAD: CUERPO, LENGUAJE Y OTREDAD EN RAÚL ZURITA Y DANTE ${ }^{1}$
}

\author{
Raquel López Sánchez \\ Universidad Autónoma de Madrid \\ Madrid, España \\ raquel.lopezs@uam.es
}

RESUMEN / ABSTRACT

Este trabajo aborda el componente de comparatismo y el fenómeno de la intertextualidad en La Divina Comedia de Dante y en la obra del poeta chileno Raúl Zurita, Zurita. Sobre la base de lo que en este artículo se ha denominado "Retórica de la mirada", el estudio de las relaciones de proximidad tematológica, estético-argumental, sociocultural, ética e histórica entre la fuente clásica y la producción de Zurita legitima no solo la importancia del lenguaje y de sus puntos de contacto con el hombre y el mundo, sino que atiende también a la amplitud del acto de mirar (ver) y de ser mirado (ser visto) en aras de la vindicación de una práctica de escritura fundamentalmente intercultural capaz de conectar y de solidarizar tiempos, espacios y relaciones entre los seres humanos (otros) en sociedad. Considerando asimismo los enfoques de la antropología literaria y de la literatura antropológica, se ahonda en el concepto de interculturalidad y en la naturaleza del discurso chileno de la postmodernidad (interdisciplinarmente integrador), para desembocar finalmente en la sazón zuritiana de un proyecto poético y vital de superación del socavamiento de la identidad y de la esperanza del lenguaje más allá de la lógica totalitarista de la imposición y del conflicto.

PALABRAS ClaVE: retórica de la mirada, interculturalidad, lenguaje, Raúl Zurita, Dante.

$1 \quad$ Este trabajo es resultado de la investigación realizada en el marco del proyecto de investigación "Analogía, equivalencia, polivalencia y transferibilidad como fundamentos retóricoculturales e interdiscursivos del arte del lenguaje: literatura, retórica, discurso (TRANSLATIO)", de referencia PGC2018-093852-B-100, financiado por el Ministerio de Ciencia, Innovación y Universidades. 
HETORIC OF THE LOOK ON THE BASES OF THE INTERCULTURALITY: BODY, LANGUAGE AND OTHERNESS IN RAÚL ZURITA AND DANTE

This work deals with the component of comparatism and the phenomenon of intertextuality in The Divine Comedy of Dante and in the production of the Chilean poet Raúl Zurita, Zurita. On the basis of what in this article has been called "Rhetoric of the look", the study of the relations of thematological, aesthetic-argumental, social, cultural, ethical and historical proximity between the classical source and Zurita's work legitimizes not only the importance of language and its points of contact with man and the world, but also attends to the amplitude of the act of looking (seeing) and being watched (being seen) for the vindication of a fundamentally intercultural writing practice capable to connect and solidarize times, spaces and relationships between human beings (others) in society. Furthermore, considering the approaches of the Literary anthropology and The Anthropological literature, we deepen into the concept of interculturality and also in the nature of the Chilean discourse of postmodernity (interdisciplinarily integrating), to finally lead to the zuritian willingness of a poetic and vital project to get over the underestimation of identity and the hope of language beyond the imposition and conflict totalitarian logic's.

KEYWORDS: Rhetoric of the look, Interculturality, language, Raúl Zurita, Dante.

Recepción: 13/05/2018

Aprobación: 11/07/2018

[...] o es un acto de fe toda mirada

"El milagro", Antonio Machado

\section{INTRODUCCIÓN: UNA RETÓRICA DE LA MIRADA EN EL PRINCIPIO DE LA COMUNICACIÓN. ZURITA Y DANTE}

Dice Zurita (Tu vida rompiéndose 137) en uno de sus poemas que "[d]entro de ella [la pupila] se refleja otra pupila que le devuelve la mirada y ese reflejo a su vez espeja a otra y esa otra a otra y a otra y a otra". La mirada no es solamente en el poeta chileno un tema que vertebre su poética desde la década de los setenta hasta la actualidad, sino también el modo en que se condensa la expresión profunda y metafísica de su escritura. A finales del siglo XX publicaba Rodríguez Fernández un sugerente estudio sobre el relato zuritiano El día más blanco, y exponía que "el que escribe [...] ve por todas partes resplandores, luminosidades del cielo y la memoria, visiones que hacen operar al relato como una arqueología de la mirada, mirada retrospectiva que pretende enunciar un mundo que ya no existe, arqueología que se debate en el problema nunca resuelto entre lo visible y lo enunciable" (Rodríguez Fernández 175). 
La poesía de Zurita se inscribe en ese paradigma donde el espacio de la experiencia real y la capacidad del lenguaje para nombrarla no siempre resuelven una correspondencia posible. Entre el mundo y la palabra, pues, la mirada es el reducto en que se avienen la representación y el signo verbal. El lenguaje trata de ajustarse constantemente para expresar el fulgor del paisaje, los centelleantes rostros de familiares y la percepción desoladora de un país roto, pero en la obra de Zurita no lo hace con el propósito de reconstituir la realidad, sino con el de "crear nuevas formas, nuevos movimientos" (Rodríguez Fernández 176); en definitiva, una "arqueología de la mirada" capaz de concebir un nuevo Chile desde la palabra que le da origen y la aleja de la circunstancia histórica opresiva de la dictadura (Vid. Fischer). Es lo que desde el pensamiento fenomenológico de Merleau-Ponty constituye la visión y el conocimiento del objeto en términos de "venir a habitarlo" (88).

La poesía de Zurita bien podría integrar igualmente el volumen editado por Sánchez y Spiller, donde se dan cita un buen número de artículos centrados en la faceta "visionaria" de la literatura con que se pretende la proposición de una "poética de la mirada" (Sánchez y Spiller 9). La producción del poeta chileno condensa lo que estos estudiosos han denominado como "arqueología" o "poética" de la mirada y que en este trabajo se postula como una "Retórica de la mirada", teniendo en cuenta la retoricidad de toda comunicación y la conciencia de esta retoricidad orientada a la construcción de discursos que proyectan un natural dominio de integración persuasiva sobre la instancia comunicativa del receptor. En tanto en cuanto el lenguaje poético recorre "los pasos de la Retórica clásica" (García Berrio 95), la constitución retóricolingüística de la comunicación zuritiana se realiza plenamente en armonía no solo con una cobertura de influencia y conexión intercultural (Vid. Llamas Ubieto), sino también con el ahormamiento de la realidad desde una poesía concebida sobre la base de la potencialidad comunicativo-visual y de las relaciones humanas en la sociedad.

Dicho de otro modo, no solo se trata de la tematización de la mirada en la poesía, ni siquiera de su reflexión como un tópos desde el que se genera la práctica de la escritura. En Zurita, la mirada es un acto humano dador de sentido al mundo; ver, mirar, supone el comienzo del proceso de la comunicación y un acto puramente retórico determinado por la superación de los "rasgos específicamente literarios de la mirada como motor de la creatividad artística" (Sánchez y Spiller 9) para radicarse en la propia invención del lenguaje, de un ars bene dicendi que permita enunciar, nombrar, tanto el mundo que es como el que podría ser a través de la cala esperanzadora de la visión. No es 
que la mirada sea el instrumento para la expresión lingüística y artística de la realidad, es que esta hace posible la creación del lenguaje, de un nuevo lenguaje (poético) cuyos códigos permiten la desarticulación y exterminio del discurso justificado por la lógica del Estado criminal (Monteleone 39; Vid. también Brito, "Un continente semiotizado" 53; Guerra 45)² y restablece la envergadura del poema en su funcionalidad comunicativa de "algo que está inscrito en lo más profundo de la idea que tenemos de lo humano" (Zurita cit. en Sánchez).

La motivación intermedial de la mirada da carta de naturaleza también para la construcción discursiva de La Divina Comedia, cuyo fundamento, refiere Zurita, se encuentra en el cruce de miradas entre Dante y Beatriz ${ }^{3}$, lo que vuelve a poner el acento sobre la tesis fenomenológica de Merleau-Ponty y el planteamiento de la percepción desde la propia experiencia corporal del individuo. Afirma este que "el cuerpo es el vehículo del ser-del-mundo, y poseer un cuerpo es para un ser viviente conectar con un medio definido, confundirse con ciertos proyectos y comprometerse continuamente con ellos" (100). En esta directriz, el conocimiento del hombre sobre el mundo toma como punto de partida su experimentación, la conciencia física y material que le permite interactuar con el medio que le rodea y con los objetos existentes en él. El cuerpo ya no solo se funda como un objeto más del mundo, sino como un medio de comunicación con este, toda vez que se define como "horizonte latente de nuestra experiencia" (Merleau-Ponty 110), esto es, la estructura que da acceso al discernimiento de los objetos de la realidad.

2 En palabras de Guerra, la lógica totalitarista "borra todo trazo cultural para imponer una creación ex nihilo [...] en una praxis de la violencia dominadora en la esfera del imperio de los signos" (45).

Según Zurita (Cit. en. Stavans), “[t]odas las virtudes con que está dibujada Beatriz son el homenaje a ese amor real vislumbrado en el mismo instante en que se perdía. Si este poema es un alegoría, lo es de algo infinitamente más cercano: es la alegoría del cruce de miradas y este cruce de miradas a la vez alegoriza la totalidad del lenguaje. Todos levantamos algo semejante al poema danteano cuando nos miramos con el otro. Todos cruzamos el Infierno y el Purgatorio cuando el otro se muere. Todos volvemos al Paraíso cuando imaginamos que ese otro muerto ha vuelto para hablar con nosotros, para decirnos lo que siempre quisimos oír y que no nos fue dicho. Así Dante, cuando escucha a Virgilio contarle que es Beatriz quien le ha encomendado que lo guiase, lo que escucha es lo que él no pudo escuchar cuando ella estaba viva. Oye entonces que Beatriz siempre estuvo preocupada por él. Ese es el primer Paraíso que nos muestra el poema". 
Desde el marco teórico-filosófico de la fenomenología, "venir a habitar" aquello que se mira, y que es mirado, significa la elucidación del hecho experiencial vivido, de ahí que la orientación fenomenológica centre el esfuerzo de sus teorizaciones en la concepción del "yo" como un sujeto incorporado al mundo, y a través de cuyo ejercicio es posible su conocimiento y comprensión. La Divina Comedia pone de manifiesto el ser viviente que es Dante, su condición de individuo conformante de la red de entidades visibles y la facultad de su mirada integrada en el ámbito de la actividad consciente. En este sentido, la totalidad del esquematismo dimensional de la obra a través del tránsito por el Infierno, el Purgatorio y el Paraíso determina la argumentación del viaje dantesco a la luz de un acto sustancial de mirar y de ser mirado, que no queda simplificado, sin embargo, a los personajes dramáticos de Dante y Beatriz, la experimentación del mundo de Dante debe entenderse como una presencia continua de la visión escrutadora de las realidades de cada círculo hasta la contemplación de la armonía de las esferas celestes y del orden de las cosas en el universo. La mirada dantesca se ensancha, así, más allá del objeto de deseo, el amor de Beatriz, para arraigar en la topografía inmoral de los cantos y en la condena de aquellos que, en definitiva, solo vivieron para sí.

La propuesta de una "Retórica de la mirada" a propósito de la poética de Zurita surge con la razón de una puesta en diálogo con el monumento clásico de la literatura italiana, ya no basado solamente en una práctica de tematología comparatista o en las relaciones intertextuales que se establecen entre sendos textos, sino también en una dinámica analógica de metabolización poético-artística del mundo de hondo calado filosófico y metafísico que tiene su raíz en la conceptualización de un linaje literario vinculado a la herencia dantesca. Los poemas de Zurita comportan la superación de las resonancias del imaginario de la Antigüedad integrando tanto los mecanismos de articulación estética de la obra artístico-verbal, como el singular contexto de actuación en que tiene lugar la producción zuritiana desde una coyuntura socio-histórica. Señalaba recientemente Rowe que la escritura de Zurita está sustentada por una radical "crisis del lenguaje" (14) y, por ende, del lenguaje poético, que caracterizó a los setenta. Su poesía patentiza no solo el conflicto político, económico y social provocado por el régimen de la dictadura pinochetista, sino también el conflicto humano, moral, identitario y cultural del hombre, bretes que asedian igualmente el itinerario de Dante al trasluz del desvío, el vicio y el egoísmo encarnados por los condenados del "Infierno" y del "Purgatorio". A la par que La Divina Comedia, el trayecto recorrido por Zurita por el espacio y el tiempo de la tarde del 10 de septiembre de 1973 al 
amanecer del día siguiente se revela de carácter cognoscitivo, habida cuenta del propio "quicio del mundo" (Merleau-Ponty 101) que es el cuerpo del hombre y de su conciencia de este mundo gracias al espesor y la presencia de este (Monteleone 29).

El descreimiento de los valores morales y de la compasión (Vid. Alvarado Borgoño, "Raúl Zurita, poeta de la compasión" 52) hacia el otro presente en La Divina Comedia sugestiona el proyecto poético de Zurita, que ve en el relato dantesco la clave interpretativa y anticipada de la agonía del lenguaje en la Postmodernidad, incapaz ya de nombrar "el amor", de nombrar "los crímenes" (Zurita 194). El pensamiento de Zurita aparece, pues, permeado por la idea romántica herderiana de la poesía como lengua primigenia de la humanidad, también por la tesis esencialista de Heidegger en su Hölderlin y la esencia de la poesía, donde atribuye al lenguaje poético la fundación original del ser. Es precisamente por cuanto "la poesía está en la base de lo humano" (Zurita cit. en Sánchez) que el tejido tematológico de la soledad y del egotismo representados por la sociedad de Dante configura un particular y anunciado fresco costumbrista del sentido trágico del siglo XX. Así pues, la búsqueda de Dante del resurgimiento de "la muerta poesía" se sitúa equidistante a la angustia zuritiana de un mundo en que la palabra ve socavado no solo su valor, sino también su significado de nombramiento y redención, algo que se hace evidente en Las palabras y las cosas, de Foucault. El horror vacui se enquista al cabo en las estructuras de un tiempo acometido por la soledad del individuo, la banalización de lo sensible y el derrumbe de las lenguas.

Tomando como punto de partida la preeminencia del lenguaje, este trabajo contempla tres objetivos fundamentales: 1) explica el componente comparatista y el fenómeno de la intertextualidad (Vid. Genette; Kristeva) en la obra del poeta chileno Raúl Zurita para significar la trascendencia del linaje literario ${ }^{4}$ derivado de aquel a través de la fuente clásica de La Divina

$4 \quad$ En este trabajo, el concepto de "linaje literario" queda significado a través del análisis comparatista llevado a término entre La Divina Comedia y Zurita, que ratifica efectivamente la herencia ética, sociocultural, histórica y estético-argumental que la fuente clásica ha legado al proyecto del poeta chileno. Este "linaje literario" puede verse en Zurita también en relación con el valioso estudio de Piglia sobre la literatura borgeana, donde aduce lo siguiente: "La literatura de Borges se construye en el movimiento de reconocerse en un linaje doble. Por un lado, los antepasados familiares, 'los mayores', los fundadores, los guerreros, el linaje de sangre. [...] Por otro lado, la investigación de los antepasados literarios, los precursores, los modelos, el reconocimiento de los nombres que organizan el linaje literario" (90). 
Comedia, fundada sobre la base del mirar y del ser mirado y de las relaciones entre el lenguaje, el hombre y el mundo -lo que se denomina "Retórica de la mirada"-; 2) saca a colación las nociones de "Antropología literaria" y "Literatura antropológica" como ámbitos metodológicos de gran impacto en el estudio e indagación de las prácticas de escritura intercultural y del discurso chileno de la Postmodernidad, y 3) aborda la problemática de la crisis del lenguaje poético en la Postmodernidad, lo que Zurita denomina el "colapso de la escritura" y la "agonía de las lenguas y los mundos" en relación con el actual ejercicio de una poesía denotadamente autista -del yo- y desprendida de la referencialidad de común estrato (inter)cultural e identitario del mundo exterior.

\section{EL ENTRECRUZAMIENTO CUERPO Y MUNDO: LENGUAJE Y OTREDAD}

Ahondando en la noción medular del lenguaje, en El arco y la lira (1955) el poeta mexicano Octavio Paz lleva a término una valiosa disertación en torno a la conceptuación de la poesía y la naturaleza del poema. La revelación del ensayo paziano se inscribe en la necesaria trascendencia del poema sobre el lenguaje, pero asume como certeza que el poeta "no se sirve de las palabras", sino que "es su servidor". De este modo, la palabra poética no resuelve un objeto de instrumentalización, sino que es servida para que recobre su naturaleza original; "servidor del lenguaje", el poeta es alguien que trasciende los límites de este, purificándolo en tanto es obra de la poesía.

Los razonamientos de Paz no solo resultan ser de gran ayuda para comprender el planteamiento de las complejas relaciones entre el lenguaje, el hombre y el mundo y, en el seno de estos, la palabra poética, sino que devienen en el quid hermenéutico para desentrañar el criterio de Zurita sobre la motivación poética, la correspondencia entre el objeto y la palabra y la natural condición del lenguaje poético para, sin dejar de ser instrumento de significación y comunicación, trascenderlas en su designación del objeto hasta alcanzar "la cosa misma, aquello que real y primitivamente [es]". En esta misma línea debe considerarse el parecer de Zurita cuando afirma que "un poema siempre es la lucha a muerte entre lo que un ser humano, el poeta, quiere decir a través de la lengua y lo que la lengua quiere decir a través del poeta" (Zurita cit. en Rodríguez). En suma, prevalece el servilismo del poeta ante el lenguaje poético; un lenguaje que es plenamente lo que es, pero que 
es también, esencialmente, ambivalente, metafórico, fundado en imágenes que "sin perder sus valores primarios, su peso original, son también como puentes que nos llevan a otra orilla, puertas que se abren a otro mundo de significados indecibles por el mero lenguaje" (Paz 22).

"[El] triunfo de la lengua [sobre la voluntad individual] es lo que ocurre con Dante y su amor por Beatriz" (Zurita cit. en Rodríguez). El lenguaje poético comporta así una superación del habla ordinaria y cotidiana, pero implica también la posibilidad narrable de aquello que permanece oculto, de lo que ha caído en la experiencia de lo terrible y no puede decirse; es por ello que "hay que volver al lenguaje [y a su naturaleza simbólica] para ver cómo la imagen puede decir lo que, por naturaleza, el lenguaje parece incapaz de decir" (Paz 106). La "Retórica de la mirada" no se yergue sobre el vacío, y tampoco lo hace exclusivamente sobre la noción del cuerpo como masa corporal visible y vidente en el mundo; lejos de todo reduccionismo, la nota más importante de su formulación es la vocación dialéctica de integración conceptual porque visión y lenguaje, mirada y palabra, uno y otro órganos del sentido expresan "el contenido de una concepción dinámica de la razón, del devenir racional, porque la razón se va haciendo constantemente, explorando incluso lo irracional e integrándolo en una razón ampliada, sabedora de que el sentido siempre aparece acompañado de sinsentido sin que esto implique la renuncia a la esperanza en una verdad" (López Sáenz 145). La racionalidad legitima la consciencia del cuerpo como un espacio eminentemente expresivo (Merleau-Ponty 163), esto es, está experiencial, sensitiva y perceptivamente involucrado en el mundo, como legitima también, a través de su interactuación y conexiones de sentido, que el pensamiento colegido del ser-del-mundo y de las pulsiones perceptivas e intencionales que sobre este se espigan queda recogido en la palabra que lo nombra y le da cauce de expresión lingüística. La sentencia de Merleau-Ponty con que garantiza que ver y conocer el mundo es "venir a habitarlo" (88) no solo refiere y explica el dominio corporal de experimentación de lo vivido por el hombre, sino que conecta también con la función designativa del lenguaje, de modo que el "vocablo, lejos de ser el simple signo de los objetos y las significaciones, habite las cosas y vehicule las significaciones. Así, el discurso no traduce, en el que habla, un pensamiento ya hecho, sino que lo consuma" (Merleau-Ponty 195).

En continuidad con estos razonamientos, y en tanto "el hombre es un ser de palabras" (Paz 30), los conceptos de cuerpo y de lenguaje se incorporan a una órbita organizativa de integración en que estas, las palabras, "estarían inscritas en el cuerpo como un modo de ser en el mundo y el lenguaje ya no 
sería solo un fenómeno comunicativo, sino una experiencia comunicativa en la que se conjugan modos de ser y visiones del mundo" (Cárcamo Landero 10; vid. también Galindo). Se deduce, entonces, que la propia palabra es también una experiencia corporal establecedora de lazos comunicativos con que exponer no solo la visibilidad, y aun la invisibilidad, del mundo, sino también los vínculos culturales, históricos, antropológicos y psíquicos que unen la intimidad del individuo con este y con sus semejantes. Desde esta perspectiva, la experiencia humana deviene en experiencia del lenguaje, estatuyéndose el hombre en la conciencia de su propio ser lingüístico de modo que esgrime la existencia de su ser en el mundo mediante el acto de expresión de la palabra, que permite, a su vez, el ingreso a las esferas de lo social y de la cultura. Se trata de lo que Merleau-Ponty define como "palabra hablante" (213), radicada en una proyección de reconocimiento de la naturaleza del propio cuerpo, en el concierto experiencial del trato con las cosas, y sustentada por el acervo de pensamientos, emociones y voluntades entendido en aras de la vindicación de un cuerpo que habla o de la experiencia corporal del lenguaje con fines primigeniamente comunicativos e interactuantes. En términos de Paredes, hay una "participación activa constante entre cuerpo y conciencia que se produce en el lenguaje. Porque el hombre es un sujeto hablante, además de ser un sujeto pensante, su presencia en el mundo se construye haciendo uso de un lenguaje que traduce en formas lingüísticas de expresión sus pensamientos y sus intenciones". Alega, además, que la "comunicación lingüística es, por un lado, una comunicación intelectual cuando la palabra se apoya en el concepto previo, sin dejar nunca de ser, por otro lado, una comunicación vital e incluso corporal, cuando la palabra no traduce un pensamiento ya hecho, sino que contribuye a formarlo" (Paredes 54).

\subsection{Sobre la baSe De LA EXPERIENCIA y DEL LENGUAJE: ANTROPOlOGía LITERARIA, LITERATURA ANTROPOLÓGICA E INTERCULTURALIDAD}

Puesto el foco de atención sobre la palabra como una experiencia corporal, no es extraño que esta "palabra hablante", en términos de Merleau-Ponty, ingrese en el campo de lo que Alvarado Borgoño ha denominado "Antropología literaria", desde la que atiende a una nueva forma de escritura que "tiene que

5 En su artículo "Introducción a la antropología poética chilena", Alvarado Borgoño subraya que la antropología poética es un tipo textual original cuyo surgimiento data de los 
considerar la materialidad del dolor no solamente propio sino también ajeno, y quizás sea el mismo cuerpo del etnógrafo, nuestros cuerpos, los que nos obliguen no solo a poetizar, sino también a pensar en la ingenua y legítima utopía de la plenitud posible" (Alvarado Borgoño, El espejo rápido 373; "El espejo rápido: notas sobre los caminos"; Analogías estéticas 59 y ss.). Estos postulados no solo alzan conexiones con el argumento de MerleauPonty sobre el lenguaje como experiencia viva y entrelazamiento cultural de este con el cuerpo y con el mundo, sino también con la obra de un Zurita que prologa El espejo rápido de Alvarado Borgoño vertiendo sus propias deducciones a propósito de esta antropología literaria. De conformidad con la propia interpretación que Alvarado Borgoño lleva a cabo de su concepto, el proyecto de Zurita se inscribe en el paradigma de una escritura que es acto de solidaridad histórica, de viaje y memoria respecto de la experiencia y el conocimiento y donde la mayor importancia la adquiere el lenguaje como constructor del mundo; el dolor de la carne propia, el de la carne otra, la mirada consciente sobre la desolación de la realidad de la dictadura, van configurando el tejido de un género textual cuyos signos lingüísticos, las palabras, son la prolongación de la experiencia corporal, acogidas una y otra a los órdenes subversivos de la experimentación y de la necesidad de sublevación individual y colectiva.

Poeta de la resiliencia, la más que posible inclusión de la producción de Zurita en el conjunto de textos designado como "Antropología Poética Chilena" (APCH) por Alvarado Borgoño ("Introducción a la antropología poética chilena" 170) confirma también su propuesta de una sustancial alteridad. El espacio discursivo de la antropología literaria es, pues, el de un encuentro con la diversidad, con la heterogeneidad, y la manifestación de una textualidad que es fundamentalmente intercultural en su vocación antropológica y etnográfica en pro de una literatura que se afana en la búsqueda de los motivos de la creación profunda del poeta en relación con una perspectiva postmoderna y de interacción con el otro (Alvarado Borgoño y Carrasco; Alvarado Borgoño, Analogías estéticas 133 y ss.).

últimos 25 años en Chile, lo que implica simultaneidad con la práctica literaria durante el régimen militar en el país (169). 
No puede soslayarse, empero, la mención al proyecto de Carrasco $^{6}$, que en 2010 publica un interesante artículo bajo el título "Literatura antropológica chilena: fundamentos" donde efectivamente postula el planteamiento de una "literatura antropológica" (Carrasco, "Poesía antropológica chilena") en el ámbito de la latinoamericanidad en general y de la cultura chilena en particular. Cuando este trabajo ve la luz, y como ocurre con toda metodología reciente, Carrasco ("Literatura antropológica chilena" 9) se apresura a indicar que este género discursivo o tendencia literaria "aún no ha sido conocido, valorado, leído ni interpretado como tal"; es con estas primeras consideraciones que va iniciándose un proceso de canonización y definición en torno a la textualidad dentro del campo literario, trasladando así el objeto de estudio desde el ámbito antropológico con la denominación de "antropología poética" o "antropología literaria". Pese a que la "literatura antropológica" y la "antropología literaria" pueden entenderse como tipos de discursos opuestos, en tanto la primera funda sus características sobre la base de la literatura y la segunda sobre la base de la antropología y de las ciencias sociales chilenas, lo cierto es que son más los elementos que permiten su complementación y reciprocidad que los que las distancian. El juego de correspondencias sustantivas y adjetivas cruzadas en sendas denominaciones viene a centralizar la cuestión de la "mutación disciplinaria" (Valenzuela 335; vid. también Carrasco, "Poesía antropológica de Ivonne Valenzuela" 221) ${ }^{7}$. Con este concepto se alude a la imposibilidad de hablar de una única disciplina -ya sea antropología literaria o literatura antropológica-, pero tampoco puede hablarse de disciplinas categóricamente aisladas; su solo tratamiento por separado resultaría inconcluso. De ahí el código que surge como integración de códigos disciplinares diversos y, a un mismo tiempo, interrelacionados.

6 Carrasco y Alvarado Borgoño llevan a cabo estas teorizaciones en el marco de una serie de proyectos de investigación Fondecyt, bajo los títulos de "Interdisciplinariedad, interculturalidad y canon en la poesía chilena e hispanoamericana actual" y "Literatura antropológica en Chile", de los que Carrasco es investigador principal y Alvarado Borgoño y Galindo co-investigadores.

7 Según Carrasco ("Poesía antropológica de Ivonne Valenzuela" 223), "[1]a mutación disciplinaria se ha establecido en una doble dirección, desde la literatura a las ciencias o las filosofías y teorías, o desde estas a la literatura, contribuyendo al aumento de discursos inter- y transdisciplinarios y a la modificación de géneros tradicionales, mediante la incorporación de elementos propios de disciplinas científicas en la poesía o el relato principalmente (historia, sociología, antropología), la ruptura de niveles y normas de género, de estilo y de contenido semántico". 
Aparte, pues, de los aspectos de una poética zuritiana en el marco de la antropología literaria, del otro lado, es decir, del costado de la textualidad literaria, la literatura antropológica refiere "la percepción o concepción de la literatura como experiencia estética de la escritura, a la literatura como forma de conocimiento de la realidad y, en grado menor, como testimonio autobiográfico del escritor" (Carrasco, "Poesía antropológica de Ivonne Valenzuela" 225). En consonancia con los presupuestos de Carrasco, y recuperando la tónica de un tipo de mirada transformativa que propicia de lo mirado un objeto de deseo, uno de los rasgos más notorios de la literatura antropológica en relación con la obra de Zurita tiene que ver precisamente con la práctica de performance del poeta a través de sus poemas en el cielo o en el desierto.

Carrasco propone el desarrollo del nivel gráfico del texto poético "mediante la visualidad concretada [por] la inclusión de fotografias, dibujos u otra clase de elementos gráficos que sirven de apoyo y configuración de temas etnográficos" ("Poesía antropológica de Ivonne Valenzuela" 226). Desde su primera obra, Purgatorio, el espacio poético de Zurita ha estado ocupado por el empleo de muy variadas formas de visualidad; son fotografías, encefalogramas, mapas, dibujos e incluso glosas y dedicatorias que contribuyen a resemantizar los contenidos del texto verbal, desde un enfoque que no solo refuerza la tesis de la concepción de la literatura como experiencia estética de la escritura, sino que también sugiere una significativa transposición del relato etnográfico a un ambiente de impacto sociocultural más amplio. El volumen Zurita cierra, por ejemplo, con toda una sección de fotografías de los acantilados de la costa norte de Chile.

Literatura antropológica y antropología literaria sugestionan, así el cruce de disciplinas, el intercambio de métodos de trabajo y la abolición de una concepción estanca del estudio de los discursos de las ciencias sociales y humanas.

Desde esta modulación integradora, la codificación semiótica tanto de disciplinas como de discursos disímiles converge en un sistema de expresión en que intervienen activamente el carácter experimental de los signos y referencialidades; las capacidades comunicativas del lenguaje en su heterogénea afección disciplinar (antropológica, sociológica, psicológica, etnológica, cultural, política e histórica, entre otras); la vivencia humano-corporal en el mundo; el contacto cotidiano con la otredad; el autobiografismo del poeta; la observación y la percepción; y la valorización de las "diversas modalidades y manifestaciones de lo humano, no solo leerse a sí mismo en los otros, sino 
también acrecentar el ser propio con la humanidad de otros" (Carrasco, "Poesía antropológica de Ivonne Valenzuela" 223). Todo lo que, por otra parte, cabría tener en cuenta cuando se habla aquí de una retórica de la mirada.

Respecto de la temática del otro, la tendencia antropológica de la poética chilena involucra tanto el entrecruzamiento del cuerpo y de la cultura recíprocamente con la fuerza motriz del lenguaje, como la dimensión expresiva de lo ajeno, y esto en lo que bien semeja un tributo al aforismo rimbaudiano "Je est un autre". De profundo calado filosófico y fenomenológico, la sentencia de Rimbaud en su carta ("Lettres du voyant") a Paul Demeny estatuye la expresión más reconocible del inicio de la despersonalización romántica culminante en el simbolismo francés (Vid. Anguita 259-260). El axioma rimbaudiano proyecta la problemática más característica de la contemporaneidad; la "búsqueda de la identidad personal" por medio de polaridades, máscaras y espejos esgrime la poética de nuestro tiempo tratando de satisfacer una insaciable voluntad de integralidad y encuentro con lo absoluto ( Vid. López Castro 27). No resulta difícil establecer el nexo con el juicio de Carrasco ("Poesía antropológica de Ivonne Valenzuela" 223) que acaba de mencionarse: es un "no solo leerse a sí mismo en los otros, sino también acrecentar el ser propio con la humanidad de otros".

En Zurita, la alteridad se construye de acuerdo con la "esencial heterogeneidad del ser" machadiana (Vid. Carreño; Siguán), cuyo patetismo reside en "el reconocimiento de la extrañeza del otro, que es siempre el comienzo de la vivencia de la extrañeza interior" (Cárcamo Landero 4). Reconocer la vivencia de otro y de uno mismo como un ser que no es totalmente accesible sin esta conciencia alter constituye una vía de concretización del sujeto único, pero también de la reafirmación colectiva. En lo inmediato, puede decirse que a esta universalidad del lenguaje, a la identificación del cuerpo-otro en el mundo y a la experiencia de este esquema triádico -lenguaje, cuerpo y mundo- como conformante de la cultura, a la que accede y de la que toma su encarnación expresiva, solo se llega si la escritura resuelve, como se dijo ya, una práctica de solidaridad, una "apelación ética" y una vocación de compromiso. La posibilidad de un lenguaje capaz de nombrar su realidad más allá de los afanes totalitaristas y los indicios de una fenomenología del cuerpo -y de la mirada- consisten al cabo en la reunión de individuos, comunidades y contextos históricos y socioculturales cuya conexión radica en la acción de la percepción humana y en un comportamiento comprometido (Vid. González y Jiménez Tavira 116; Alvarado Borgoño, "Raúl Zurita, poeta de la compasión" 52). 
La voz de Zurita aparece, pues, timbrada con la ética del perdón (Cit. en Alvarado Borgoño, El espejo rápido 19) ${ }^{8}$ levantada por Dante en la metafísica medievalista de La Divina Comedia. Texto y contexto del lenguaje poético apuntan en su dialéctica hacia la retórica de la mirada como un principio fundamental y definitorio del complejo engranaje de la comunicación, a que se adhieren, por su relevante significación antropológica y cultural, las nociones del proyecto de Carrasco y Alvarado Borgoño: la literatura antropológica y la antropología literaria La declinación de todos los valores de la sociedad dantesca, su contemplación en el tránsito del Infierno, el Purgatorio y el Paraíso, y la encarnación del mundo en la palabra trazan un panorama completo por el que la hermenéutica clásica de Dante penetra las estructuras poéticas de Zurita hasta copar un espacio significativo cuyo sentido prevalece supeditado a "una actividad perceptiva orquestada por nuestro cuerpo" (González y Jiménez Tavira 118) prolongado a la realidad.

\section{EL INFIERNO CORPORO-POÉTICO DE ZURITA (2012): UNA APROXIMACIÓN}

La obra magna Zurita desborda con la experiencia más traumática de su vida: su apresamiento y tortura en las bodegas del carguero Maipo tras el golpe de Estado de Pinochet. En relato no se origina en el espacio del Infierno, sino en el del Purgatorio. El Purgatorio, espacialidad a medio camino entre el horror de la sombra y la redención edénica, es el lugar en que la voz zuritiana encuentra los motivos de su interlocución; si cabe afirmarlo así, no podría haber sido de otro modo: el carguero Maipo significaba la mitad de la travesía, el espacio en que se desciende a la descarnada aflicción de los desdichados,

\footnotetext{
Resulta indispensable la consulta del trabajo de Bello Reguera (1998), galardonado con el Premio Internacional de Ensayo "Jovellanos" en 1997. En este estudio se aborda no solo la expresión de la otredad, sino también un aspecto fundamental como es la bioética o ética de la vida humana en relación con las conexiones existentes entre las sensibilidades de los diversos rostros, o cuerpos, que no solo siguen la estructura de la interpelación del otro, sino que también acceden a ser interpelados. El parangón con el acto de mirar o de ver y de ser mirado o ser visto es más que evidente, y se funda asimismo en la afirmación de la responsabilidad histórica más allá de la autonomía del yo o del entorno particular en que se inscribe la individualidad.
} 
pero también en que resuenan infinitos ecos de esperanza. Es la esperanza de un nuevo lenguaje y, con él, de una nueva realidad.

La obra primera de Zurita, Purgatorio (1979), inicia el ciclo de poemas bajo el título "En el medio del camino" con una evidente marca de intertextualidad endoliteraria (Vid. Martínez Fernández 81) que saca a colación el comienzo del clásico de La Divina Comedia: "En medio del camino de la vida" (Infierno I, v. 1: 8). La "selva oscura" (Infierno I, v. 2:8) dantesca viene dada en esta obra por el espacio íntimo de un aseo en que Zurita "destroza su cara tremenda / frente al espejo" (Zurita 144) ${ }^{9}$. Así, la cubierta de Purgatorio reproduce la fotografía de la mejilla izquierda de Zurita, que el propio poeta quemó con un fierro candente. La unión que se establece entre el lenguaje (poético), el cuerpo y el mundo tiene en la acción extrema de Zurita una justificación casi gráfica desde los puntos de vista fenomenológico, biosemiótico y retórico que tratan de explicar sus relaciones y entrecruzamientos como una evidencia comunicativa y una certeza del acceso al conocimiento desde la experiencia y la percepción. No solamente el cielo y el desierto constituyen singulares soportes de escritura y de dinamización material del signo, sino que también la propia corporalidad (baste recordar la quemadura en su mejilla) del poeta se significa al servicio de lo irrealizable lingüístico-verbalmente; el drama de la dictadura es el drama de la palabra, y es también el del cuerpo individual, el del cuerpo otro y el del cuerpo social que es la patria chilena. En este sentido, en su conversación con Brito ("Conversación con Raúl Zurita") refiere Zurita que se debe "[...] interiorizar la vida en la poesía y exteriorizar el arte en la vida. Así, Purgatorio es un libro, pero también la marca de mi mejilla, un tránsito literario, pero también un tiempo concreto de vida. El Purgatorio es mi tránsito por la experiencia de lo precario y doloroso de la vida" $(23)^{10}$.

\footnotetext{
9 A partir de este punto solo se indicará la página de referencia de Zurita entre paréntesis.

$10 \quad$ El contexto en que confluyen el arte y la vida en Purgatorio ha sido estudiado por Tarrab ("Intertextualidad científica"), que ve en la faceta artística "un orden ejemplar de resistencia" ante los actos de represión. Se entiende así la adscripción de Zurita al Colectivo Acciones de Arte (CADA), que hizo frente a la barbarie de la dictadura constituyendo sus formas de protesta y denuncia en soportes expresivos en expansión dirigidos a la conciencia social y colectiva. En palabras de Neustadt, "[...] el Colectivo de Acciones de Arte / Chile reúne a un grupo de trabajadores culturales que asumen el arte como una práctica científica de producción de vida. Es decir, como un modo operatorio de reasignación de los valores y parámetros socioestéticos a considerar en la creación colectiva de una nueva realidad. [Se propone] entonces el arte como una práctica teórica de intervención en la vida concreta de
} 
La estructura trimembre de Zurita, cuyo título expande la idea de la búsqueda de la identidad tras el golpe y la necesidad del acceso del lenguaje a la realidad nombrada, se renueva amén de un ubicuo recorrido por el 11 de septiembre de 1973 que jalona paratextualmente la obra en tres tiradas poéticas: "Tu rota tarde", "Tu rota noche" y "Tu roto amanecer". En la primera de estas tiradas, se representa la escritura en los acantilados de "frases de amor, de locura y de muerte" (18), esto es, los puntales temáticos de la poética zuritiana donde el carácter polifónico del texto no solo evoca la voz narrativa de Dante, sino que también sugiere la presencia de una intertextualidad exoliteraria ( Vid. Martínez Fernández 81) que se hace manifiesta a través de las palabras en el dintel de la puerta del Infierno: " $¡ O$ Oh, vosotros, los que entráis, abandonad toda esperanza!" (Infierno III, v. 9: 15). Es sobre la base de esta intersección temática que van construyéndose la común red de sentido y la entidad dialógica y semántica de los versos. Como acontece en el viaje dantesco, Zurita no irá solo; la organización del mundo zuritiano traspasa la subjetividad personal chilena para incorporarse al terror atávico de nuestra contemporaneidad.

El complejo poético "Tu rota tarde" se desgrana con naturalidad en el fluir de la narración del "desahuciado atardecer" (23) del lunes 10 de septiembre de 1973. Bajo el revelador título "Cielo abajo" se superpone un catastro de imágenes familiares y de espacios arrasados, todo ello desde una retórica fundada en la fuerza biológica de un universo apocalíptico. Con el verso "Mi vida es vacía" (24) se produce un intercambio más que digno del verbo copulativo; el patetismo y la violencia de la expresión introducen el viaje zuritiano iniciado en "Cielo abajo". El viaje de Zurita no se adentra en el averno, sino que permanece en la ciudad real, que ya es, de por sí, un infierno en la tierra; los versos sitúan al lector en el lecho yermo de unas calles abismadas, donde los nombres de seres amados y los espacios urbanos van esgrimiendo una poética telúrica de lo infernal (Vid. Tarrab). En este sentido, y sobre la base de la condición global que define Zurita, los personajes y referentes humanos que transitan sus versos, sujetos todos con que establece el diálogo, resuelven, unas veces, la caterva de condenados a cuyos crímenes,

Chile, lo que significa hacer de los modos y de las exigencias propias de la producción de vida, el antecedente orgánico, el soporte material y el lugar de consumo final del trabajo de arte" (113). Vid. también Brito ("Un continente semiotizado" 57) y Aros Legrand (102-103). 
guiado por Virgilio, asiste Dante, otras tantas, la compañía del poeta chileno a través de los círculos dantescos.

Es esta una ósmosis que se pone al servicio de la representación dionisíaca de Zurita. Por un lado, tanto el poeta como sus seres amados aparecen realizando el trayecto por el Infierno del extremo de los vivos, donde la figura de Veli, la conciencia nostálgica de su abuela, revierte en un particular Virgilio del seno familiar; por otro, los personajes zuritianos oscilan situándose en la orilla de los despreciados tanto por la misericordia como por la justicia (Infierno III, vv. 49-51: 15). Este caso de intertextualidad tematológica conecta sendas obras mediante la experiencia y la mirada, el mirar y el ser mirado y, en suma, la palabra en que el acontecer desolador del mundo queda encarnado. El entrecruzamiento textual se produce en el vestíbulo del Infierno del Canto Tercero, de modo que los personajes de Zurita se construyen tanto desde la perspectiva del viajero contemplador de los indolentes, como desde la de la representación de los rostros otros y familiares de Zurita como ignavos, a los que el poeta se refiere con desprecio tras la pérdida de la identidad (Vid. Fabry, "Trayectorias de la pérdida: una lectura al sesgo de las obras de Raúl Zurita y Juan Gelman") por la circunstancia de la dictadura ${ }^{11}$.

Asimismo, el barquero custodio -Carón-que impidiera en un principio el paso de Dante por el Aqueronte permuta en los versos de Zurita (30) en un botero augur de los desgraciados entresijos de los ríos de Chile, en cuyas aguas vagan las almas vislumbrando la necesidad de búsqueda del remanso. El plano de lo real y el de lo alegórico se suceden integrando escenas como las del filme Sueños de Akira Kurosawa, donde concurre una doble extensión de la otredad. Por un lado, esta otredad se significa por la interacción de códigos semióticos diversos -verbal e icónico-; por otro, el montaje del cuarto sueño del filme en que los soldados japoneses desconocen que están muertos a su salida del túnel, motiva en Zurita la afiliación temporal, histórica y vital con el cineasta. El quiasmo arte / vida resuelve también un requerimiento para el director cinematográfico, lo que permite trazar una homología comparatista desde un enfoque interdiscursivo. Así, como ha señalado Deeny, "[a]mbos encajan el problema de qué hacer con una experiencia colectiva de violencia

11 Como ocurre en La Divina Comedia, se trata de personajes desdibujados, asolados por la dureza del régimen; ni la caridad de Dios se apiada de ellos ni la justicia divina los condena. 
extraordinaria, las ruinas de la posguerra, y, más importante aún, el estado de los vivos, como los soldados trágicamente confundidos" (39-40).

En el tránsito particular de Zurita por el cono invertido, la serie de composiciones "Cielo abajo" constituye el fresco testimonial de un Infierno pertrechado en la tierra misma; los parajes por que su voz se precipita substancian una epifanía bien definida del orbe dantesco, cuya cartografía queda asumida en los versos zuritianos a la luz de un paisaje regido por la estampa bélica y la impronta del locus eremus.

La explicación hermenéutica de este Infierno no puede sino partir del padecimiento, de un delirio enquistado en la intimidad del poeta a raíz de la fatídica experiencia del régimen pinochetista; sin embargo, más allá de las cordilleras chilenas y de la metáfora del rostro humano tematizada por la arena del desierto de Atacama, la poética de Zurita desborda la referencialidad patria hasta copar la expresión de otras realidades históricas que arraigan también en un panorama desesperanzador: Hiroshima, Dresde, Bagdad. En términos de Fabry, se produce la ruptura "con una visión encerrada en el espacio nacional chileno" y tiene lugar la superposición sitemática de "varias temporalidades y espacios en una misma enunciación" ("La ficción histórica" 279; vid. también "Las visiones de Raúl Zurita y el prejuicio de lo sublime"). Las referencias espacio-temporales más frecuentes en Zurita son tres: el pasaje bíblico correspondiente al paso del Mar Rojo, la Segunda Guerra Mundial y la historia de Chile marcada por la dictadura. La sucesión de poemas contenidos en la serie "Cielo abajo" de "Tu rota tarde" inaugura así una dinámica de universalidad de la desolación que está llamada a afianzarse en el decurso de la obra a través de un discurso a medio camino entre la confesión interior y el relato de la exasperación prójima.

\section{EL DESCENSO Y EL PAÍS DE HIELO: LA MIRADA (INTERCULTURAL) SOBRE LOS DESAPARECIDOS Y LA BÚSQUEDA DE LA IDENTIDAD}

Como se ha visto, "Tu rota tarde" transcurre entre los empréstitos biográficos del poeta, la reminiscencia del contexto socio-histórico y la demarcación de un paisaje -tanto natural como urbano- atenazado por las "vísceras sangrantes" (127), el asedio de las patrullas y el presagio del "muerto amor" (146). La eclosión de "Tu rota noche", sección segunda en que se divide Zurita, está precedida por el clamor adventicio de la noche del 10 de septiembre de 
1973. Lejos de incorporarse esta segunda escena zuritiana a la jerarquía del "Purgatorio" dantesco, la granazón semántica de la deyección humana se impone sustentando la continuidad del "Infierno". De este modo, la composición que antecede a "Tu rota noche", titulada "Imborrables erratas" (236), aparece poniendo en tensión la perspectiva del ensueño -la vislumbre de un amor redentor abriéndose paso entre las tinieblas-y la referencia histórica precisa, que surge con la distorsión de la epifanía del encuentro y con la imagen "imborrable" de los tanques. El ensueño de la mirada se desvanece y la voz del poeta vuelve a adentrarse en un nuevo pórtico de insoportable dolor:

... Amor mío, ven a buscarme en la noche blanca y
negra. Mis ojos te ven entre las sombras y no sé
si habrá tiempo para el nuevo día. Los tanques,
como imborrables erratas, ya han comenzado a
horadar la luz cenicienta del próximo amanecer. (236)

Es un buen ejemplo este de lo que en este estudio se ha denominado retórica de la mirada atendiendo a las relaciones entre el cuerpo, el mundo y el lenguaje. En este sentido, los ojos de Zurita buscando la mirada otra, el objeto de su amor, entendimiento y compasión más allá de sí, no solo responden al pulso del lenguaje como una experiencia corporal (mirar al otro, mirarse en el otro, ser mirado por el otro), sino que también legitiman la experiencia comunicativa del cuerpo humano en la realidad histórica y cultural, también emocional, de su contexto vivencial. Entre las sombras de la "noche blanca y negra" sin certeza de nuevo día, esto es, en el límite de la visión y de la voluntad de ver, la palabra se alza para dar nuevamente el sí a la unión con el mundo.

Si se recuerda el "Proemio" del Purgatorio de La Divina Comedia, el enamorado de Beatriz deja atrás el hemisferio boreal en que ha contemplado a Lucifer abandonando terribles procelas, como alegan los versos dantescos, "por correr mejor mar" (Purgatorio I, v. 1: 205). No existe en el segundo escalafón zuritiano, por el contrario, presagio alguno de la purga espiritual que dignifica al espíritu humano en su ascensión al cielo. Como un tintineo constante en el decurso de todo el poemario, la serie "Cielo abajo" vuelve a regir las primeras páginas de esta sección jalonando un escenario conturbador en que convergen el bramido enloquecido de una naturaleza y una ciudad hechas ceniza y la certidumbre de prevalecer, también ahora, en el mar de la desesperación.

"Tu rota noche" es la división poemática en que se impone la referencia al episodio del Éxodo bíblico, donde Moisés, llevado por la voluntad divina, 
se yergue portaestandarte de la liberación del pueblo de Israel. Los versos zuritianos dejan traslucir inicialmente una idéntica imagen de redención mediante la división de las aguas; "cortados a pique, los dos enormes muros de / agua se [irguen] de golpe rompiendo la naciente / noche [...] al mirar hacia la / bahía me di cuenta que efectivamente era una / liberación: el mar se había abierto y nuestra / angustia tocaba a su fin" (243). Sin embargo, entre los gritos y cantos de júbilo de la muchedumbre en libertad, la dicha trueca con la contundencia de la Batalla de Santiago de 1957, escenario en que la muerte rezuma "cortando las calles / céntricas de una ciudad que solo una demencia / demasiado extrema permite aún llamar Santiago" (244). El marco de la desolación no resulta meramente del contexto de las protestas del 2 y del 3 de abril de 1957 contra la represión de Carabineros de Chile; más allá de la atmósfera bélica, la identificación familiar irrumpe de nuevo en los versos significando la huida del niño Zurita y la de su hermana, tomados de la mano y ataviados con sus uniformes escolares.

En Zurita, la geografía del cosmos concebida por el poeta florentino adviene en conjunción con la perspectiva invertida del cono infernal; si en La Divina Comedia Dante emprende el periplo descendente y cada vez más angosto y doloroso de los círculos que conforman el cráter de la precariedad moral, las composiciones zuritianas no solo están escritas desde la entraña misma del infierno individual y colectivo del hombre, sino que responden también a una concepción de la mirada desde lo alto, una pulsión de enjuiciamiento que desde la altitud huidobriana del cielo -piénsese en Altazor-asiste a la desvergüenza y la desolación telúricas.

Con las series "Barracas" y "El país de tablas", "Tu rota noche" resuelve un truculento recorrido por las prisiones y campos de concentración chilenos en lo que constituye la recreación intertextual del Canto Duodécimo dantesco $y$, por ende, la del primer recinto del "Séptimo círculo", en que agonizan los violentos contra el prójimo. El mar en que se desarrolla la segunda división zuritiana testimonia el tránsito a través de un océano de influencia bíblica que deja al descubierto las ruinas emergentes del golpe pinochetista. He aquí algunos versos ejemplificadores: "El paso del mar se había hecho más hondo cuando / las primeras construcciones emergieron de golpe, / atravesadas entre los grandes murallones de agua [...] Anoto entonces el fulgor de la nieve y una ciudad / diseminada entre las barracas: Berlín, invierno, / 2002. / Anoto la sigla de la agencia de intercambio / DAAD, y la calle donde vivo: Storkwinkelstrasse, / 22" (265). 
En estos versos, el ejercicio de la escritura poética vehiculada por las formas del verbo "anotar" ("Anoto entonces el fulgor de la nieve y una ciudad / diseminada entre las barracas: Berlín...") y el dominio semántico del poema radicado en la mirada (“... miro al frente el / edificio de la Storkwinkelstrasse completamente / arrasado [...] Alcanzo aún / a ver las últimas barracas hundirse...") reclaman una atención especial que aúna la concreción espacio-temporal ("Berlín, invierno, / 2002") y la comunicación visual como una tematización más del código de la percepción y de la capacidad comunicativa de la vivencia. La interferencia en la red de conexiones con $L a$ Divina Comedia queda justificada en esta ocasión a través del diálogo textual con las "ruinas del infierno"; las palabras iniciales del primer recinto del "Séptimo círculo" rezan como sigue: "llegamos al lugar de la bajada, / y es tan hondo y alpestre su barranco / que la vista rehúye horrorizada" (Infierno XII, vv. 1-3: 65). Al amparo del descenso de los vates de la antigüedad por el cubículo profundo de los violentos, la poética de Zurita conviene en la recreación de un mismo recorrido descendente. La hondura del paso del mar en que van superponiéndose las imágenes de las prisiones chilenas y el recuerdo individual de la estancia del poeta en Berlín configuran un crisol donde las ciudades arrasadas enfatizan la vislumbre de la ira bestial de aquellos "tiranos / de sangre y robo por su mal consejo; / que así lloran sus daños inhumanos" (Infierno XII. vv. 104-106: 69).

Con la sinergia de espacios imaginarios, paradójicos y alegóricos, la representación del cono en Dante y en Zurita sugiere la cartografía de un dolor atávico desgajado de la revelación de la corruptela de un tiempo que excede la mera individualidad para perpetrarse en la depravación universal. Con ello, desde la hondonada cruenta del mar, la contemplación de Prisión Tres Álamos, Prisión Chacabuco, Prisión Colonia Dignidad, Prisión Isla Dawson, Prisión Estadio Chile o Villa Grimaldi se estatuye no solo como la escenificación del horror de los torturados, sino también como la idónea resemantización de los violentos contra el prójimo dantescos, esto es, los simpatizantes del régimen de Pinochet. En el Éxodo de las Sagradas Escrituras el peregrinaje de los hijos de Israel entre las aguas del mar hacia la tierra prometida de la libertad trastabilla en los versos zuritianos con los inmensos murallones de agua descubriendo a cada paso el maderamen de un país de tablas, la conciencia chilena derruida y sollozante ante la visión desoladora de las cárceles, los cuarteles, la caterva de cadáveres y el hervidero sangriento de sus despojos "todavía / clavados todavía rotos con los ojos todavía abiertos / mirando desde esas barracas la mirada muerta del océano" (275). La serie de 
composiciones que conforman "El país de tablas" simboliza como ninguna el entrecruzamiento del cuerpo y el mundo, así como la presencia del nódulo del lenguaje. Lo que se plantea es, precisamente, la prolongación comunicativa de la experiencia corporal y emocional, la fusión de los paisajes chilenos con la carne humana ( Vid. Tarrab, "Prólogo") sometida al yugo de la dictadura.

El "Descenso" al Infierno prosigue en la sección homónima - "Y como una sombra muerta / seguíamos bajando entre los murallones del mar" (288)-, en que también se encuentra la serie de composiciones bajo el epígrafe "Hielos". Situado en el "Noveno círculo" dantesco, el Cocito es igualmente asimilado por la poética de Zurita; en puridad, el lago gélido en que se aprisionan las almas de los traidores intensifica en el poemario zuritiano el eco del horror a través de los "Retratos en los témpanos" (303), donde son los rostros de sus seres amados los que perecen en los "congelados paredones del desfiladero del mar" (306). Se versifican aquí los ojos de Ana Canessa, que el poeta ve enrojecer "detrás de los / hielos" (306); la cara inmovilizada y abandonada en los hielos de Iván Zurita; los labios contraídos, y los mechones de pelo rojo de Felipe Zurita emergiendo tras el glaciar.

Desde esta perspectiva, de la transfiguración de los desleales y alevosos dantescos en la retórica del retrato familiar zuritiano no puede sino colegirse el sentido trágico de la miseria humana perpetuada en la desolación de los vencidos frente a la perfidia de los verdugos. Madres, hijos, entre otros rostros allegados se sitúan así en el extremo de los condenados, intensificando con ello la ignominia del Infierno a través del escarmiento de los inocentes. La serie de composiciones bajo el título "El país de hielo" esgrime el culmen de la travesía infernal dantesca ensanchando el helor en el habitáculo del "Noveno círculo" no solo hacia la topografía de Chile, sino también hacia el resto de países de América Latina, América del Norte o África, en lo que deja traslucir una hermenéutica global del infierno en la estera de la Creación Universal. El "doloroso reino" del hemisferio boreal dantesco constituye, al término del viaje por el Infierno en su contemplación de Lucifer, el símbolo del desamor que abunda en Zurita: "El desamor congeló entonces el Pacífico / uno frente al otro sus paredones eran dos / enloquecidos témpanos estrechándonos" (313).

Se ha referido ya. No hay en la obra Zurita una visión cerrada y exclusiva de la espacialidad nacional chilena; el texto poético, por el contrario, se hace eco de otros territorios y tiempos con el propósito de integrar en un mismo sistema antropológico, social y cultural la experiencia y la emoción de diversos caracteres etnográficos. A este respecto, y con acierto, ha señalado Fabry que la postura mesiánica de Zurita consiste en el "derecho e incluso el deber [...] de acortar el tiempo al estrechar las correspondencias entre las 
distintas capas históricas" (“La ficción histórica” 281-282). El conflicto que permea los poemas de Zurita no reivindica solamente una memoria autóctona, el relato del sufrimiento se "multiplica y se desplaza [...] a una sensibilidad desterritorializada y transhistórica" (Fabry, "La ficción histórica" 282; vid. Zurita, "Sobre el amor, el sufrimiento y el nuevo milenio") que asume el refuerzo del lenguaje poético como un soporte comunicativo con los sucesos del pasado y luchas de sentido en otros espacios nacionales, con su adherencia sociocultural e histórica. Desde la óptica de la literatura antropológica y la noción de interculturalidad, se trata del "traslado de contenidos históricos, contingentes y referenciales desde la historia [otra] a la conformación de un poema" (Carrasco, "Literatura antropológica chilena" 11) que da en comunicar una suerte de hibridación cultural.

Sobre la base de este ensanchamiento territorial e histórico, la escritura de Zurita apunta a la narración de la alteridad bajo diversos prismas hermenéuticos. El discurso sobre la construcción del otro se contextualiza en "las señas de una identidad que permanentemente se erosiona, se pulveriza, se vuelve sentido, se transforma en cultura" (Zurita, Los poemas muertos 17). La evidencia del cuerpo propio es también la certeza del cuerpo otro, que se concreta bajo el lenguaje de entrecruzamientos y transfiguraciones identitarias supeditado a la mirada. El punto de convergencia entre el otro y el yo fundamenta su sincretismo de acuerdo con un desdoblamiento al modo rimbaudiano de la escisión de la identidad, cuya premisa es la de una alteridad objetiva que conecta el dolor del ser ajeno con el padecimiento propio. Así, Zurita no entraña solamente una poética de carácter universal en que tiene cabida la experiencia profundamente individual y también la expresión colectiva, de encuentro y de comunicación con los demás; es igualmente una búsqueda de la identidad del yo a través del lenguaje y de la visión de la realidad que han sido usurpadas por el discurso de la dictadura.

Desde la integración conceptual y fenomenológica que rigen la mirada, el cuerpo, el lenguaje y la otredad, el dualismo entre lo individual y lo universal se suprime "en la medida en que el habla misma es la expresión profundamente individual de un sentido universal" (Verano Gamboa 269) que trasciende la latinoamericanidad y supera las fronteras de otros territorios en desgracia, todos ellos significados como "países muertos" o "países ennichados" (333 y ss. $)^{12}$. Se

12 La sección concerniente al poemario Canto a su amor desaparecido se articula de conformidad con la significación de la serie textual de los "Hielos" y las referencias al 
evidencia así el carácter intercultural de la poética de Zurita, donde el sesgo de la literatura antropológica establecida por Carrasco refrenda la permanente interacción de los seres humanos, su situación de contacto intercultural, el modo de conexión con el otro y la mixtura de experiencias socioculturales e históricas en diversas realidades (vid. Carrasco, "Poesía antropológica de Ivonne Valenzuela" 224-225; vid. también Valenzuela 337).

En la poesía de Zurita, la mirada hacia la interculturalidad tiene que ver con una textualidad que se ubica, efectivamente, en una semántica de la alteridad y de lo antropológico que en esta segunda parte del poemario enfatiza la significación de los desaparecidos y la recuperación de la identidad individual y colectiva a través de la interacción de sociedades, de linajes generacionales y espacio-temporales donde lo esencial consiste en una dimensión fenomenológica -también gestáltica- de la experiencia corporal como experiencia de lo vivido, de lo habitado por el conjunto de la comunidad, de lo mirado, lo percibido y, finalmente, de lo que es capaz de ser expresado a través del lenguaje.

El sentido de la otredad en Zurita principia con ese indicio fenomenológico de la percepción tan insoslayable para Merleau-Ponty, conectado con la experimentación del cuerpo y con las capacidades expresivo-designativas de la palabra; mirar, conocer la realidad, es venir a habitarla. Lejos de una hipótesis reduccionista en torno a una concepción epistemológica de la percepción, esta no implica una "ciencia del mundo [...] sino el trasfondo sobre el que se destacan todos los actos y todos los actos se presuponen"

Cocito de Dante, en que el frío apunta temáticamente a un espacio desapacible, de desamor y egotismo extremos. La tematización del desamor aparece bajo la forma de un particular empleo del espacio gráfico, donde la escritura se dispone configurando un cementerio en dos galpones con treinta nichos. Como ha señalado Garrido Alarcón a propósito de la construcción de una "ciudad para la memoria", "cada nicho es un caligrama cuadrado lleno y, al mismo tiempo, un poema en prosa, representando un nicho. [...] Aparecen distribuidos de manera que el blanco de la página se convierte en una nichería que los aloja y así todo el libro pasa a ser un columbario. El nicho sería una forma cerrada [...] creada especialmente para esta obra. La función de un nicho es alojar un cuerpo. [...] Cada nicho incluye la descripción, el testimonio, la memoria poética, de aquello que necesita ser enterrado pero no olvidado. [...] Así la necrópolis, ciudad de la memoria, en la que se describen los horrores sucedidos, es también una imagen (aunque distópica) del Cosmos. Espero del mundo que, mediante un juego de sinécdoques, va de lo individual a lo colectivo en tres etapas concatenadas: persona-ciudad (de la memoria)-país. Esta singular articulación permite que el Canto supere la coyuntura espacio-temporal de los abusos de la dictadura en Chile para erigirse en un canto universal de dolor y memoria [dirigido a una pluralidad de países]" (166-168). 
(Merleau-Ponty 10). El sujeto y el objeto, quien mira y aquello que es mirado, no suponen solamente referencias explícitas susceptibles de ser situadas en el mundo, sino que, por encima de esto, ambas instancias quedan fundidas "en una experiencia que encarna toda vinculación con el mundo, al que nuestro cuerpo pertenece, naturalmente" (González y Jiménez Tavira 115-116). Este enfoque permite considerar teleológicamente una acepción ontológica del acto de la percepción a que se accede por este mismo acto. Así, el hombre está en el mundo, pero cuando se vuelve hacia sí lo que encuentra de ese dogmatismo recibido -y contenido en el mundo exterior- es "un sujeto [la visión de un yo propio] brindado al mundo" (Merleau-Ponty 11), encarnado en él, y que le devuelve, desde la corporalidad propia y otra, la conciencia y el sentido de su inclusión en el cuerpo sociocultural e histórico de todos los seres que alguna vez han mirado, de los que han construido la historia y la tradición, en definitiva.

En relación con lo anterior, la urgencia del nuevo lenguaje a que hace referencia Zurita conecta con la resignificación de la realidad chilena más allá de las estructuras del régimen, lo que exige igualmente no solo la recuperación de los desaparecidos para cerrar las heridas del duelo, sino también de la memoria de quienes precedieron en aras de una unicidad social y cultural llamada a dignificar el sentido de la patria y su proyección futura. Este anhelo de reconstitución y de futuro puede considerarse una manifestación de lo que ya se denominó "mirada transformativa", es decir, aquella que concibe su orientación en pro de un objeto de deseo de acuerdo con la conciencia y las esperanzadoras expectativas del individuo.

Ahondando en las relaciones intertextuales entre Zurita y Dante, la interculturalidad aparece también en La Divina Comedia, donde el poeta florentino crea espacios de intersección al representar sociedades permanentemente en crisis. El privilegio temático sobre la idea de viaje, además de presentarse como procedimiento de búsqueda del intimismo y de la profundidad del ser humano en su trayecto hacia la unidad y la perspectiva holística y trascendente, consolida en la escritura dantesca el modo por que se alcanza la descripción detallada, esto es, el conocimiento de la experiencia ajena, de las cualidades etnográficas y culturales y los mecanismos de interacción de los hombres a través de la permanencia y de los modos de ser y de vivir en los diversos círculos. El viaje de Dante resuelve, pues, la apuesta por una rigurosa penetración del conocimiento del pecado humano y por la conciencia de la incorporación de la desolación universal a las estructuras cognitivas particulares, lo que desborda en la búsqueda de la redención mediante la 
ascensión al Empíreo. Con ello, el discurso del discernimiento holístico de La Divina Comedia -"En su profundo ser, vi cual se interna, / en un volumen por amor atado, / cuanto el vasto universo descuaderna" (Paraíso XXXIII, vv. 85-87: 600)- reverbera en las estructuras del Infierno zuritiano a tenor de un sentimiento universal que subyace: el Amor.

Quedó dicho. "El país de hielo" versado por Zurita no responde sino al espacio dantesco más próximo a la presencia de Lucifer, de ahí que la expresión predominante de la serie poética sea el "desamor", en que es necesario adentrarse para alcanzar la luz de la salvación. La serie de poemas "No habrá nada", que se construye en consecuente interpolación con los "Hielos", hace hincapié en una disposición bien significada que enfatiza el deceso del amor allá donde solo prevalecen los gélidos paredones del Infierno profundo: "No habrá nada, nada fuera del escarchado / mar y de los témpanos. /Al frente, sepultada bajo los glaciares, la / costa de Chile se alcanza a transparentar / y las luces del puerto de Valparaíso / siguen encendidas bajo el casco de hielo / como si el amanecer también se hubiera / congelado" (321).

No cabe la duda: la contundencia semántica del desamor encuentra su máxima expresión en la serie de poemas reunidos en "Canto a su amor desaparecido". La interpelación poética "Ma dove ti sei perduto?" (453), reza la crónica de quienes buscan la respuesta a la tortura, a la muerte y a la desaparición de sus seres amados. ¿Dónde ha quedado a la postre el amor? "Pegado a las rocas, al mar y a las montañas" (354), sentencia Zurita.

\section{4. "MI VISTA, MÁS FIJA Y MÁS SINCERA, / EN LA ALTA LUZ ETERNA Y VERDADERA": LA MIRADA DE DANTE Y ZURITA}

"Tu rota noche" abrocha con el apercibimiento del 11 de septiembre de 1973, mientras que "Tu roto amanecer", presagiando el alba, se aleja de la diafanidad naciente en el "Purgatorio" e imperante en el "Paraíso" dantescos. Las imágenes familiares despuntan nuevamente en largas tiradas versiculares que se acercan al carácter de la prosa poética y que se construyen textualmente sobre el escenario de la desolación, simbolizado mediante un sol que se abre paso en la penumbra de la muerte.

La tercera sección en que se divide Zurita no denota la presencia de los espíritus contemplativos o espíritus triunfantes de La Divina Comedia; antes bien, el ascenso de la escala celeste acusa nuevamente tanto el desbordamiento 
de la experiencia infernal como la carencia del amor a través de un amanecer teñido de rojo sangre.

Cierto es, sin embargo, que en "Tu roto amanecer" se perciben numerosas recurrencias semánticas a la elevación o el ascenso, irradiaciones verbales que contravienen la reiteración imaginativa de la serie de poemas "Cielo abajo". Del mismo modo, las aguas opresoras de la sección "Tu rota noche", que ingresaban en las entrañas profundas de la tierra y en el fárrago pecaminoso de la humanidad, permutan aquí si no en una trascendentalización temática, sí en la urdimbre de un enjuiciamiento divino desde lo alto.

No se trata ahora de un peregrinaje en descenso, sino de una mirada que se eleva desde las ciudades arrasadas en el mundo hacia la contemplación del cielo, donde se reúnen el desastre terrenal y lo que en Zurita es una especie de locus líquido ${ }^{13}$. En este plano, y a lo largo de toda la sección "Tu roto amanecer", el agua se define como el elemento de creación universal en correspondencia precisa con la identificación del "agua-madre" de Bachelard (103) y cuya fuerza poética se deja ver con claridad en el ciclo de composiciones "Las ciudades de agua".

En La Divina Comedia, la contemplación del Empíreo revela un espacio de conciliación espiritual en lo que se ha venido considerando como el apogeo del cristianismo surgente en el tardomedievo; la consecución del reino de la verdad, fundante de la paz universal, estatuye la confirmación de la creencia y la fe en la concepción del teocentrismo. El viaje de Dante es, efectivamente, un trayecto hacia su propia identidad, lo que no queda tan claro es una interpretación profundamente asentada sobre la base de la contemplación de Dios. El linaje escatológico en La Divina Comedia, como en Zurita, es irrebatible, pero abogar por otra dirección interpretativa sobre el desenlace del relato dantesco no solo permite acercar posturas entre los textos de Zurita y Dante, sino también imprimir, sobre el discurso de $L a$ Divina Comedia, un planteamiento más próximo a la disciplina antropológica e intercultural. En este estudio se postula el convencimiento de que la visión inenarrable ${ }^{14}$ de Dante, guiado en el trigésimo tercer cántico por San Bernando, no corresponde a la de Dios, sino a la de una figura humana: "Dentro de sí,

13 Zurita se refiere a este locus como "gigantescos acuarios transparentes" (58), cuya cualidad especular se configura a modo de mirada regresiva hacia el interior del hombre.

$14 \quad$ Escribe Dante en los versos 121-123: "No alcanza mi palabra a lo que evoco, / para pintar las celestiales llamas, / iy es tanto, que no basta decir poco!"' 
con su color pintada, / me pareció mirar nuestra figura, / reconcentrando en ella la mirada" (Paraíso XXXIII, vv. 130-132: 602).

Que sea un rosto humano, una figura idéntica a la "nuestra" el punto donde la mirada queda reconcentrada al término de La Divina Comedia deja al trasluz la hipótesis nada deslucida de un diario de viaje y de unas "técnicas de la observación participante" (Carrasco, "Poesía antropológica de Ivonne Valenzuela" 121) que culminan en la asunción de la identidad propia que daba origen al viaje de Dante, el autoconocimiento de la soledad del individuo y la tenencia única de sí mismo frente a la existencia de todo los demás. Según la lectura de Zurita (Cit. en Stavans), solo al final se descubre que "lo que vio Dante en el último canto del Paraíso no fue Dios, sino su propia cara, es decir, el color de la faz de lo humano recortado contra el fondo de las estrellas, con su infinita soledad". Ya se trate del propio rostro de Dante contemplándose a sí mismo en el círculo central, ya de un otro, la cuestión esencial estriba en la aseveración de un ser de disposición quiasmática, esto es, "como ser de dos caras, al igual que yo, desplegado hacia el mundo y hacia los demás, ininterrumpidamente" (González y Jiménez Tavira 128).

Situados aquí, la idea consiste en la sustentación de la carnalidad inherente al hombre y en la proclividad de esta para la percepción; el carácter observatorio frente al otro que configura estructural y temáticamente el viaje de La Divina Comedia no puede sino dirigirse, al final del relato, hacia la conciencia de la mirada, establecida primero con Beatriz, con los personajes diversos del Infierno, del Purgatorio y del Paraíso, después; y hacia el discernimiento de una alteridad profundamente humana con la que el hombre debe convivir. Penetrando en el sumidero abierto de la interpretación, hay una cala de sentido esotérico de acuerdo con las posibilidades de recepción de un texto puramente místico, tal y como lo han concebido prioritariamente los estudios críticos, pero tanto La Divina Comedia como Zurita se nutren de un espacio que sobrevive a la lectura alegórica, donde la voluntad de la lengua se impone a la intención de quien escribe. Entran estos presupuestos en consonancia absoluta con lo que ya refirieran Paz o Zurita: los grandes poemas son aquellos en que el lenguaje se revaloriza y se antepone al propósito poético individual. No es extraño, de este modo, que en el último cántico de La Divina Comedia prevalezca un sentimiento de incomprensión a propósito de "cómo se combina la naturaleza mortal con la divina" (Paraíso, XXXIII: 597). La calidad alegórica de que los poetas revisten el texto literario termina por ubicarse en un segundo plano, mientras que la voluntad de la propia lengua, la inconsciencia del lenguaje, confiere primacía al plano literal sobre el alegórico. 
Dentro, pues, de las resonancias bíblicas y símbolos escatológicos, la mención de Dios en estas obras esgrime un argumento poético desarrollado para cubrir, o suplir, la carencia de Dios. El precepto dantesco del "renazca la muerta poesía" se convierte en guía textual de los tercetos de La Divina Comedia y firma la inexistencia de Dios; lo que Zurita ha justificado a lo largo de su producción como su retiro, mejor aún, su deserción, de la historia humana.

Una vez abandonada la idea del sometimiento providencialista, cobra fuerza el significado de la mirada que se eleva, una mirada que sigue siendo humana, que se alza desde la tierra y que pone su capacidad de juicio y de observación al servicio de su reunión con la naturaleza; con el cielo, con las estrellas, con lo universal -"Y medio a medio del cielo sobre el mar suspendidas / las ciudades parecían caras mirándonos / Agrandándose como los ojos de Dios" (563)-. Los objetos, los seres y las situaciones de referencia en la realidad de Zurita se suspenden, se reflejan, se espejean construyendo una sólida simbología: la mirada de todas las cosas contemplándose, aprendiéndose unas a otras como un eterno retorno donde el lenguaje, la percepción y el contacto con el (lo) otro pretenden el autoconocimiento de la naturaleza humana, la comprensión interna y externa del ser y de las cosas que le rodean, un modelo de solidaridad histórica entre culturas y civilizaciones, la memoria de los desaparecidos y sacrificados y la recuperación de la identidad individual y colectiva mediante la actividad socio-comunicativa y reconstituyente de la palabra frente al fascismo de los militares.

\section{CONCLUSIONES: UNA MIRADA HACIA LA INTEGRACIÓN INTERDISCIPLINAR}

En síntesis, un estudio principalmente comparatista como el que se ha llevado a término en las páginas precedentes, y sustentado especialmente en las marcas de tematización intertextual sobre la base de las obras poéticas Zurita y La Divina Comedia, está lejos de reducir sus posibilidades de indagación a términos metodológicamente intrínsecos como la reescritura, la transposición -semántica, sintáctica y pragmática- o la propia intertextualidad. El carácter transversal del comparatismo sugiere ya no solo su conexión y dependencia respecto del marco distintivo de la ciencia de la literatura, sino también un sesgo de expansión que compete a las ciencias humanas y a las ciencias sociales. En este sentido, el gran avance de los estudios que ha tenido lugar 
en todos los campos disciplinares especialmente a lo largo de los siglos XX y XXI y la dedicación reflexiva y esmerada tanto a aspectos centrales como a rasgos periféricos de las diversas materias y metodologías y de los objetos de estudio, abre paso a una más que necesaria integración (inter)disciplinar que permite seguir con la tarea de explicación y descripción de diversos sistemas de conocimiento.

El objeto poético de que parte este estudio nos ha llevado a formular lo que se ha denominado bajo el sintagma "Retórica de la mirada", considerando, no obstante, la presencia de muchos otros trabajos incardinados en la naturaleza y calidades de la visualidad, atendiendo efectivamente a motivos axiales como el cuerpo, la percepción, el mundo -interno y externo-, el lenguaje y la otredad. Sobre la base -conexionada y comunicativa- de todos estos conceptos se cimenta la homología argumental, temática, estética, social, histórica y cultural, pero también fenomenológica, antropológica y, como decía Paredes, "vital", que es posible establecer entre la obra del poeta florentino y la del chileno; entre la crisis política, económica y social del Quattrocento y el golpe totalitarista de 1973. El planteamiento de esta retórica de la mirada surge de la intersección, es decir, del punto en que lenguaje y experiencia del mundo se condicen respectivamente para dar carta de naturaleza a la vivencia del ser (palabra hablante) y a las comunes interactuaciones comunicativocorporales de la humanidad. Es por este motivo que la tesis fenomenológica de Merleau-Ponty y sus teorizaciones en torno a la percepción constituyen un buen soporte para empezar a desgranar el sentido de mirar y de ser mirado, de ver y de ser visto y, en último lugar, de concebir la sensibilidad visual sobre el objeto en términos de "venir a habitarlo" (Merleau-Ponty 88); esto es, percibirlo, vivirlo, comunicarlo.

La recuperación de otra voz poética como es la del mexicano Paz sirve para dar cuenta de las complejas relaciones entre el lenguaje, el hombre y el mundo y muy principalmente para otorgar a la poesía un cariz de revelación de la cosa misma nombrada y designada por la condición trascendentalista de los poetas. La lengua es, en efecto, la que finalmente rige la dicción del poeta, asumiendo en esta una constitución esencialmente metafórica, polivalente, que, paradojalmente, logra penetrar la significación profunda tanto de la realidad que puede decirse, como de aquella cuyos accesos al lenguaje aparecen velados por la barbarie de la civilización y de los sucesos históricos cometidos por esta. Como diría Zurita, la palabra se responsabiliza del espacio de lo inenarrable, que suele ser el lugar de los puntos suspensivos (Zurita cit. en Serra Bradford) y, por ende, de lo que adquiere una dimensión 
difícilmente igualable a la emoción humana que debería dar origen a la palabra; estos puntos suspensivos como una alegoría infalible de la lentitud a merced de la reflexión y de la marcación dramática que implica desnudar el alma humana. La experiencia corporal del lenguaje o la experiencia lingüística del cuerpo sugieren un quiasmo que en el caso latinoamericano en general y en el chileno en particular sacará a colación las nociones de un interesante proyecto concebido por Alvarado y por Carrasco: la antropología literaria y la literatura antropológica. Ambas disciplinas concurren en una serie de aspectos que delimitan la experiencia de una escritura marcadamente heterogénea, y donde se condicen y entrecruzan las diversas disciplinas que aspiran a la articulación de una gran expresión de la interactividad humana. Antropología literaria ( Vid. Alvarado Borgoño, "La aparición de la antropología literaria chilena"; "Introducción a la antropología poética chilena"), desde el ámbito de conocimiento de la antropología y literatura antropológica, desde el ámbito de la literatura, esgrimen una forma de escritura novedosa por cuanto implican la superación de las fronteras o del anquilosamiento de las formas de comunicación o diálogo entre la disimilitud -tan solo relativa- entre las prácticas de campos de trabajo distintos.

La importancia de su mención en este estudio es elevada, no solo porque ambas entrañan una orientación metodológica muy oportuna para centrar la temática -mejor dicho, la estructura organizativa e ideológica- de los razonamientos que llevan a la construcción de La Divina Comedia y de Zurita, sino también porque, dados los elementos configurativos de la textualidad zuritiana, resultaba imperativo referirse a los estudios, proyectos y planteamientos que recientemente han empezado a ganar terreno y congruencia en el marco de los discursos chilenos de la Postmodernidad, que concitan los ámbitos de lo científico y de lo literario articulando un tipo textual de interesante hibridez. De la incidencia de la antropología en la literatura y la influencia de lo literario en la antropología clásica surge un área de sorprendente análisis de la producción textual de escritores, poetas y antropólogos que dan el sí a una espacialidad sincrética desbordante en la cuestión de la interculturalidad.

Como ha señalado Cárcamo Landero en el caso de la antropología literaria, esta "empieza a tener un discurso sobre sí mismo que es el primer paso para ser libremente 'sin pena ni miedo' (como diría Zurita) y poder entrar así en la lucha por el reconocimiento de su identidad como texto genuino de las humanidades en nuestra América" (9). El cuerpo, tan importante en la antropología literaria chilena, marca una escritura que es carne, un lenguaje prolongación del cuerpo y de su contacto con la alteridad de la naturaleza, 
del mundo y del ser otro; en este sentido, y en esa búsqueda de la diversidad sociocultural, que es también la de la identidad individual y colectiva de una y de otras sociedades y nacionalidades, lo vivido del cuerpo conecta con la veta fundamentalmente literaria del testimonialismo autobiográfico y experimental del poeta, y con la evocación del viaje literario y humano desde las afecciones emocionales y cognitivas de la mirada, la observación y la percepción.

Todos estos elementos, junto con el desgajamiento argumental y práctico -empírico-que se deriva de estos, permean el análisis de Zurita y de La Divina Comedia no solo desde una perspectiva metodológica comparatista radicada en el concepto de intertextualidad, fundada sobre la base de la preocupación sociocultural, sino que lo hacen también desde y hacia un horizonte donde la ciencia del otro -y el lenguaje, también- encuentra la capacidad de apelación o influencia persuasiva al sentido ético, histórico-solidario y utópico definido por la interculturalidad y por la producción de un discurso (inter)disciplinar y humanamente integrador.

El carácter dialógico y polifónico de la interculturalidad, como también de la intertextualidad, se hace cargo, pues, de la superación de lo que Zurita ha considerado con malestar como "el colapso de la escritura" y "la agonía de las lenguas y de los mundos" (Zurita cit. en Rodríguez), lo que se proyecta a través de dos máximas causativas. Por un lado, la pérdida del lenguaje y de la identidad-del significado, en definitiva-a raíz de un suceso sociohistórico y político devastador como lo son todos los conflictos dictatoriales, bélicos $\mathrm{y}$ de intereses de imposición de un régimen abusivo y opresor; por otro, la de(s)marcación en la llamada y vivida Postmodernidad de una práctica poética fijada en el solipsismo intimista y en el relato de la tribulación monódica. Esta es la agonía: “[e]l derrumbe del lenguaje y de las lenguas es el fracaso de nuestra unión con lo que se nombra, o lo que es lo mismo, es el fracaso infernal del amor" (Zurita, Los poemas muertos 195-196). Y esta la esperanza: "Que renazca la muerta poesía". Una visión a la vez coetánea y profética la de Dante; una mirada universal la de Zurita: la de "reconstruir un paraíso perdido que sobre todo era una disposición, una acogida de lo otro y del mundo y que fue posiblemente el origen de todo mito y más tarde el origen de la poesía" (Zurita, Los poemas muertos 196). 


\section{BIBLIOGRAFÍA}

Alighieri, Dante. La Divina Comedia. Trad. Bartolomé Mitre. Ed. Nicolás Besio Moreno. Buenos Aires: Centro Cultural "Latiunt", 1922.

Alvarado Borgoño, Miguel. "La aparición de la antropología literaria chilena". Cinta de Moebio: Revista de Epistemología de Ciencias Sociales 8 (2000): 169-175.

“Introducción a la antropología poética chilena". Estudios Filológicos 37 (2002): 169-183.

"El espejo rápido: notas sobre los caminos de la analogía estética latinoamericana". Revista Latinoamericana de Ensayo, Junio (2005): s.p.

El espejo rápido: interculturalidad y prevaricaciones discursivas. Valparaíso: Editorial Puntángeles, 2006.

Analogías estéticas y comprensión transcultural latinoamericana: El vuelo de la calandria. Tübingen: Narr, 2015.

"Raúl Zurita, poeta de la compasión y de los desiertos capitales". Hispanic poetry review 1 (2016): 51-65.

Anguita, Eduardo. Anguitología: selección de poesía y prosa. Santiago de Chile: Editorial Universitaria, 1998.

Apolinário, Lourenço. Identidad y alteridad en Fernando Pessoa y Antonio Machado. Salamanca: Universidad de Salamanca, 1997.

Aros Legrand, Pablo. "Visión del cuerpo: un recorrido corporo-textual a partir de los años setenta en Chile”. Philobiblion: Revista de Literaturas Hispánicas 4 (2016): 91-106.

Bachelard, Gaston. El agua y los sueños: ensayo sobre la imaginación de la materia. México: Fondo de Cultura Económica, 2003.

Bello Reguera, Gabriel. La construcción ética del otro. Oviedo: Ediciones Novel, 1997.

Brito, María Eugenia. “Conversación con Raúl Zurita”. APSI, 76 (1980): 23-24.

"Un continente semiotizado en femenino: la escritura de Raúl Zurita". Campos minados (Literatura post-golpe en Chile). Santiago: Editorial Cuarto Propio, 1990.

Cárcamo Landero, Solange. "La antropología literaria: el lenguaje intercultural de las ciencias humanas”. Estudios Filológicos 42 (2007): 7-23.

Carrasco, Iván. "Literatura intercultural chilena: proyectos actuales". Revista Chilena de Literatura 66 (2005): 63-84.

y Miguel Alvarado Borgoño. "Literatura antropológica chilena: fundamentos". Estudios Filológicos 46 (2010): 9-23.

"Poesía antropológica de Ivonne Valenzuela". Anales de Literatura Chilena 17 (2012): 219-236.

"Poesía antropológica chilena”. Chile en el siglo XXI: ¿Nuevos recorridos artísticos, nuevos caminos históricos? Eds. Laetitia Boussard y Benoit Santini. Santiago de Chile: Piso Diez Ediciones, 2014.

Carreño, Antonio. “Antonio Machado o la poética de la otredad". Cuadernos Hispanoamericanos 304-307 (1976): 527-536. 
Deeny, Anna. "El amor en primera persona". Zuritax60. Textos críticos sobre su obra. Ed. Paulina Wendt. Santiago de Chile: Mago, 2011. 35-41.

Fabry, Geneviève. "Las visiones de Raúl Zurita y el prejuicio de lo sublime". Cahiers $d u$ monde hispanique et luso-brésilien 99 (2012): 239-255.

"Trayectorias de la pérdida: una lectura al sesgo de las obras de Raúl Zurita y Juan Gelman”. Revista Iberoamericana 247 (2014): 471-492.

"La ficción histórica en dos poemarios recientes: Cuadernos de guerra de Raúl Zurita y Nombres propios de Yaki Setton”. Studi Ispanici 41 (2016): 275-290.

Fischer, Marie-Louise. "El día más blanco o el país de la memoria de Raúl Zurita". Iberoamericana, América Latina, España, Portugal. Ensayos sobre letras, historia y sociedad 17 (2005): 55-63.

Foucault, Michel. Las palabras y las cosas: una arqueología de las ciencias humanas. Madrid: Siglo XXI de España Editores, 2006.

Galindo, Óscar. "Interdisciplinariedades en las poesías chilena e hispanoamericana actuales". Estudios Filológicos 39 (2004): 155-165.

García Berrio, Antonio. Teoría de la literatura (La construcción del significado poético) (2 ${ }^{\mathrm{a}}$ edición revisada y ampliada). Madrid: Cátedra, 1994.

Garrido Alarcón, Edmundo. "Construir una ciudad para la memoria: Canto a su amor desaparecido". Revista de Filología Románica 6 (2008): 161-171.

Genette, Gérard. Figuras III. Barcelona: Lumen, 1989.

González, Roberto Andrés y Gabriel Jiménez Tavira. "Fenomenología del entrecruce del cuerpo y el mundo en Merleau-Ponty". Ideas y valores 60 (145) (2011): 113-130.

Guerra, Lucía. Ciudad, género e imaginarios urbanos en la narrativa latinoamericana. Santiago: Editorial Cuarto Propio, 2014.

Heidegger, Martin. Hörderlin y la esencia de la poesía. Ed. Juan David García Bacca. Barcelona: Anthropos Editorial, 2000.

Kristeva, Julia. "Bajtin, la palabra, el diálogo y la novela". Intertextualité. Coord. y Trad. Desiderio Navarro. La Habana: UNEAC / Casa de las Américas, 1997. 1-24.

Llamas Ubieto, Miriam. Lecturas del contacto: Manifestaciones estéticas de la interculturalidad y la transculturalidad. Madrid: Arco / Libros, 2011.

López Castro, Armando. "Antonio Machado y la búsqueda del otro". Estudios Humanísticos: Filología 28 (2006): 27-47.

López Sáenz, Ma Carmen. "Merleau-Ponty o el arte de la visibilidad". AGORA. Papeles de Filosofia 17 (1998): 145-165.

Martínez Fernández, José Enrique. La intertextualidad literaria (Base teórica y práctica). Madrid: Cátedra, 2001.

Merleau-Ponty, Maurice. La fenomenología de la percepción. Barcelona: Planeta, 1993.

Monteleone, Jorge. "Una mirada corroída. Sobre la poesía argentina de los años ochenta". Culturas del Río de la Plata (1973-1995). Transgresión e intercambio. Ed. Roland Spiller. Lateinamerika-Studien 36, Universität Erlangen-Nürnberg, Frankfurt am Main: Vervuert, 1995. 203-215. 
Neustadt, Robert. Cada día: la creación de un arte social. Chile: Cuarto propio, 2001.

Paredes, Ma del Carmen. “Cuerpo y sujeto humano". Daimon: Revista de filosofia 18 (1999): 41-56.

Paz, Octavio. El arco y la lira. México: Fondo de Cultura Económica, 1986.

Piglia, Ricardo. "Ideología y ficción en Borges". Punto de vista 5 (1980): 87-95.

Rodríguez Fernández, Mario. "Una arqueología de la mirada: El día más blanco, de Zurita”. Revista Chilena de Literatura 55 (1999): 175-177.

Rowe, William. "Tiempo y medida en Purgatorio de Raúl Zurita”. Mitologías hoy. Revista de pensamiento, crítica y estudios literarios latinoamericanos 15 (2017): 13-20.

Sánchez, Yvette y Roland Spiller, eds. La poética de la mirada. Madrid: Visor Libros, 2004.

Santini, Benoît. "El cielo y el desierto como soportes textuales de los actos poéticos de Raúl Zurita”. Revista Laboratorio 1 (2009): s.p.

Siguán, Miguel. "El tema el otro en Antonio Machado". Homenaje a Jaime Bofill y Bofill. Convivium 21 (1966): 267-286.

Tarrab, Alejandro. "Prólogo" a INRI. Raúl Zurita. Madrid: Visor, 2004.

"Intertextualidad científica en Purgatorio de Raúl Zurita". Zuritax60. Textos críticos sobre su obra. Ed. Paulina Wendt. Santiago de Chile: Mago, 2011. 141-168.

Valenzuela, Pilar. "Literatura antropológica en Chile: una manifestación de literatura intercultural". Revista Chilena de Literatura 96 (2017): 333-349.

Verano Gamboa, Leonardo. "El lugar del otro: el problema de la alteridad en la filosofía de Merleau-Ponty". Universitas Philosophica 58 (2012): 251-275.

Zurita, Raúl. Sobre el amor, el sufrimiento y el nuevo milenio. Santiago de Chile: Editorial Andrés Bello, 2000.

Los poemas muertos. México: Editorial Libros del Umbral, 2006.

Zurita. Salamanca: Delirio, 2012.

“Traducir La Divina Comedia: Conversación con Raúl Zurita”. Entrevista a Raúl Zurita por Ilan Stavans. Proyecto Patrimonio. 2013. Recuperado de: www.letras.s5.com, Página chilena al servicio de la cultura dirigida por Luis Martínez Solorza.

Tu vida rompiéndose. Santiago de Chile: Lumen, 2015.

"Dante es la gran alegoría de la muerte de la poesía". Entrevista a Raúl Zurita por Juan Rodríguez. El Mercurio. 20 de septiembre, 2015. Recuperado de: http://www. economiaynegocios.cl/noticias/noticias.asp?id=184690

“Entrevista a Raúl Zurita”. Entrevista a Raúl Zurita por Arturo Sánchez. Clé des Langues. 02 de agosto, 2016. Recuperado de: http://cle.ens-lyon.fr/ojal/entrevista-a-raulzurita-296467.kjsp

"Raúl Zurita, el poeta que sabe decir". Entrevista a Raúl Zurita por Matías Serra Bradford. Revista Ñ. 12 de agosto, 2016. Recuperado de: https://www.clarin.com/rn/ literatura/Raul-Zurita-poeta-sabe-decir_0_BydC_YuDme.html 